\title{
ENGLISH LANGUAGE EDUCATION AND CHARACTER BUILDING FOR ELEMENTARY STUDENT THROUGH STORYTELLING BASED ON UPANISAD STORIES
}

\author{
Ni Nyoman Ayu Nikki Avalokitesvari
}

\begin{abstract}
This article aimed to describe the role of storytelling based on Upanishad stories on English language education and character building for elementary student. Storytelling is the original form of teaching and has the potential of fostering emotional intelligence and help the child gain insight into human behavior. Storytelling also promotes language learning by enriching learners' vocabulary and acquiring new language structures. Moreover, storytelling can provide a motivating and low anxiety context for language learning. There are several stories derived from Purana and Upanishad. One of those story from Upanishad that can be used to build a strong and good character as well as training them to learn English for kids in elementary school is the story of Nachiketa.
\end{abstract}

Keywords: English Language Education, character building, Storytelling, Upanishad Stories

\section{Introduction}

Globalization of Technology brings a lot of alteration towards kids nowadays. They have to deal with the use of technology so it wouldn't harm their self as technology is a two side of swords. Hence, to use and even mastery the technology they have to learn English as it is the basic and common language to operate several tools and application as well as software used in technology nowadays. Furthermore, to make sure they won't get negative impact from technology itself, they must have a good and strong character. There are several ways to combine both English lesson and character building for elementary student. One of them is storytelling.

Storytelling is the art of narrating a tale from memory rather than reading it. It is one of the oldest of all art forms. Storytelling is the original form of teaching and has the potential of fostering emotional intelligence and help the child gain insight into human behavior. Storytelling also promotes language learning by enriching learners' vocabulary and acquiring new language structures. Moreover, storytelling can provide a motivating and low anxiety context for language learning. Therefore, many EFL 
(English as a Foreign Language) are interested in storytelling as a resource in teaching. Teacher should choose an appropriate story. A good story to build children's character must have positive moral value. Those kinds of story can be derived from Purana or Upanishad.

There are several stories derived from Purana and Upanishad. One of those story from Upanishad that can be used to build a strong and good character as well as training them to learn English for kids in elementary school is the story of Nachiketa.

\section{Effectiveness Storytelling in English Language Education}

There already several experimental evidences which shows the effectiveness of Storytelling for English Language Education. Chaudron (1988) focuses on teacher talk and on student behavior and interaction in the classroom. He also focuses on the interactions between teachers and the ESL learners. He argues that the most important thing with the research is to produce descriptions of classroom events and the relationships that occurs, since studies like this are very important for teachers, learners and learning. Meanwhile, a study by Speaker (2000) provides evidence that students who are frequently exposed to stories develop their oral language more easily than those who are not. Furthermore, this exposure also helps them to attain a higher level of language proficiency Students, who are active participants in their language learning, learn in a social context, while they are interacting with other students and adults.

Furthermore, Speaker (2000) states that there is evidence concerning the positive aspects of Storytelling. Students and teachers should be encouraged to use Storytelling in the teaching both from an ESL and L1 (first language) perspective. Skolverket (2011) argues that students shall be given the opportunities to develop their language in correct school context; this shall be addressed regardless of which language (first or second) you are supposed to develop.

Anoter study was conducted by Isbell, Sobol, Lindauer and Lowrance (2004). They try to find out how Storytelling influences first language development. In the study, two groups of students got to hear the same 24 stories. One of the groups heard the stories told, and the other group heard the stories read from a book. The language samples were transcribed and analyzed. The results from this study showed that results from both Storytelling and story reading were found positive when it 
came to developing oral language skills. They could also see differences between the two different methods used. Young students who heard stories told orally showed improved comprehension in their retelling, while the students who were read to show improved language complexity. Speaker (2000) writes: Children involved in Storytelling programs exhibit improved listening skills, better sequencing, abilities increased language apprehension and more thoughtful organization in their own writing. The benefits of becoming familiar with the concept of an oral tradition are numerous. Ghosn (2002) writes about how students learn through interaction with others. Through a narrative form of teaching, all students' language can be developed on the different levels they are at. Students learn and develop at their own pace in interaction with others. To be in contact with an advanced language does not become negative when the support is in the form of classmates and adults in the classroom.

Hence, with this finding, we can see that working with Storytelling for language development is beneficial and rewarding. From the ESL perspective, we can see that teachers are very positive to Storytelling. Many of them find Storytelling more important when the students are learning a new language. Since the students cannot read, they find Storytelling a good way to introduce a subject. They are then able to discuss words and meanings that are new to the students instead of them having to read it themselves. This way of teaching promotes students' oral skills (Ghosn, 2002).

\section{Character Building through Storytelling}

Character building or Character Education is a process of transferring and acquiring values to children (Ulusoy and Dilmaç, 2012). It includes many aspects of teaching and learning for personal development such as reasoning, social and emotional learning, moral education, life skills training, community service, health education, prevention of violence, peer mediation and ethics (Demirel, 2009). The purpose of character education is raising children as insightful, caring, high-minded, righteous people and individuals who use their best capacity to do their best, and who understand the purpose of life (Lake, 2011). It also helps children to get to know and desire for the good and engaged in good actions eventually.

However, transferring of values to children and putting into practice in their lives is not as easy as it is expected, the use of various 
methods and media is necessary. One of them is storytelling. Children get to know the worlds of different characters through stories and being inspired from these, they can create their own emotions and thoughts without hesitation (Zeigler, 1992). Discussion of these stories in a followup activity enables students to gain knowledge and experience of these positive social attitudes and behaviors such as sharing, collaboration and helping (Uzmen, 2001). Story is an important tool in the socializing of the child and the transfer of the traditions to future generations along with the role it plays in the preservation and expansion of existing values (Court \& Rosental, 2007). Because children enjoy when the parents and teachers read them and they become aware of cultural beliefs and values through implicit messages. Also, stories introduce the world of words to the children, provide a feeling of general satisfaction and makes life fun and entertaining (Choudhuri, 2005).

Storybooks support character education and it is important for a sustainable human development. Stories are important educational tools that will help model behaviors to be transferred and placed into human consciousness (Edgington, 2002). Dilidüzgün (1996) states that highly imaginative children cannot establish logical relationships like adults do, that there is a different mechanism of their minds. He adds that a child of this period is appealed by stories containing both imaginary and real elements and the parallelism between the logic constructed in the story and the thinking of the child. Impact that stories are one of the fundamental elements that educate the society. Human being has narrated his own life truth, solution offers, and expectations by ascribing to stories and characters and for centuries, they have tried to warn, educate and equip future generations for the hardships of life. Children would identify themselves with the characters in the stories, and for this reason, the characters should bear positive qualities. Different genres of children literature offer important opportunities to teachers as they facilitate association of values with daily lives (Edgington, 2002; Karniol, 2012).

Several studies also believe that Storytelling can build a good character towards children because from good stories that parent telling to their kids, they can learn about morals, manners, strength and perseverance, logic and imagination. For example, your parents might have taught you morals through myths and parables when you were young. These same stories have been passed down for generations and it is also your 
responsibilities now to share these myths and parables to your children. Parables are especially important because they hold so much meaning. They are in fact meant to teach children moral ethics and the meaning or purpose of life. Using stories to teach your children morals is also a perfect way of showing them the cause and effects of doing something that is immoral. When you repeat these stories over time, children will remember the moral ethics and the way to behave much better than if you would just tell them what to do.

Another prominent characterbuilding benefit from storyteller is using stories to teach your children manners. In today's interconnected world, manners are social skills that one cannot live without. As an old saying goes, "manners maketh man" and you will be doing your children a favour by teaching them manners like how we were taught by our parents. Your children will go a long way in life just by having good manners. In many children stories, the protagonist would usually go through certain trials before reaching a "happily ever after". In stories such as these, children learn about strength and perseverance. They would grasp the concept of working hard towards their goals, shouldering the trials and making it through with inner strength and perseverance. Such qualities are essential for children to learn so that they will be able to go through life's challenges in their adult years.

Logic may not be always present in children's stories, especially those with certain fantasy elements in them. However, for older children, you can teach them logic by asking them if they think that the stories are a reflection of reality. By teaching them to differentiate between stories and real life, you also train your children to understand the reality of life and how they should bring logic into everything that they encounter in their lives. Besides all the above qualities, storytelling also helps to build your children's imagination. They would begin to remember the story's plot, its characters and then use their imagination to picture how everything looks. With this training, your children will hone their creative skills that will help them to get out of unpredicted situations in their later lives.

All the above can build your children's character and help them to grow up into logical individuals who can differentiate between right and wrong. Your children will also be individuals who would stand by their own principles, set their goals and pursue them in the right manners and attitudes. They would become valued individuals in the society and can be independent in all that they do. All it 
takes for you as a parent is to help them by using storytelling as part of their education through their growing up years.

\section{The Story of Nachiketa}

Thousands of years ago, at a time when the paths of Gods and Men were not so different from each other, there was a sage called Vajashravas, who had a young son called Nachiketa. Vajashravas, whose name means "Famous for charity", used to perform big 'yajnas' or fire-sacrifices, at the end of which he gave away wealth, cattle, food and other possessions as alms to the poor. (Per Hindu scriptures, such good actions and giving carry the giver into the world of heaven!) While Nachiketa, whose name means "Fire of the spirit" was an intelligent, loyal boy with an incredibly strong spirit that nobody could shake!

Once, at one such yajna, Nachiketa noticed something really WRONG - he saw that the cows his father was giving away were old and barren - they had no more milk to give, nor could they have calves!

Nachiketa thought, "Oh no, this is cheating! True charity means giving away things that are good and useful, not old and useless! Such faulty charity will not earn my father a spot in heaven for sure!"
Then he thought to himself, "What if I get my father to give ME away for charity? I am young, strong and useful! Surely, giving me away will balance out my father's mistake!"

So, he approached his father and asked, "Dear Father, to whom will you give me away?

Vajashravas was busy and did not heed him. Thereupon, Nachiketa asked the same question again and yet again, until finally, his father lost patience and became angry.

“I WILL GIVE YOU AWAY TO YAMA, THE LORD OF DEATH!" Vajashravas shouted!

Vajashravas immediately regretted his outburst, as he certainly did not mean this. But that was an age when one's word was to be honoured at any cost. Nachiketa, good boy that he was, consoled his father and set off for the house of Lord Yama.

Now as it turned out, Lord Yama was not home when Nachiketa arrived. But Nachiketa had promised, and he meant to keep his promise. So, he stood outside Lord Yama's home for three days and three nights, without food or water, awaiting his return! When Lord Yama finally returned, he was horrified to see this young Brahmin boy standing outside in such a state! He immediately took him inside, gave him water and food, and begged his forgiveness. (In that 
age, if one had a Brahmin guest at one's home, it was a grave sin not offer him food, water and rest.) To make up for the hardship suffered, Lord Yama offered Nachiketa three boons.

What would a normal boy his age asks if he were given three boons? Riches? Good food? Toys? Friends and companions, music and fun?

But no, Nachiketa was a special child indeed. He joined his hands and requested Lord Yama, "As my first boon, I ask for my father's peace of mind. Let him not grieve for me any longer."

Lord Yama was surprised at the unselfish wish, and quickly granted him the boon, reassured him that he would soon go back to his father, and all would be well.

Then, Nachiketa, the intellectually curious child, requested, "As my second boon, I ask you to teach me the "Fire Rite". My father says, this is the rite which is the key to attaining immortality in heaven!"

What a boon to ask! Lord Yama was intrigued and very pleased indeed! And when he taught him the rite, Lord Yama was even more pleased by Nachiketa's intelligence and quickness at memorizing what he was taught! To honour Nachiketa, Lord Yama renamed the "Fire Rite" to “Nachiketa Rite".
For his final boon, Nachiketa asked Lord Yama, "Please tell me what happens at the end of life."

Lord Yama was truly shocked. "This subject is too difficult for even great Gods!" he told Nachiketa. "Ask for something else. Ask for a long life, power, riches, grand chariots, friends, a big family - anything you want! Just don't ask me about this!"

But the brave Nachiketa was not swayed. "Of what use are your chariots, music and dance to me? I know these will not last forever! So, keep them to yourself!" he said. Oh, what a brave boy! TO SCOLD THE LORD OF DEATH HIMSELF!

Lord Yama was truly amazed and bowed before Nachiketa's steadfastness with deep respect.

"Nachiketa," he said, "There are two paths in life -Shreyas (the Good) and Preyas (the Pleasant). Most people choose the pleasant, because the pleasant is easy and the good is difficult. But those who give up the pleasant in favour of the good are truly wise! And you are such a noble soul... you gave up a long life, wealth and pleasure for that which is truly worth knowing. You are indeed a spiritually advanced soul!"

Then, Lord Yama gave Nachiketa the precious answer that he was seeking. On hearing this answer, Nachiketa became enlightened. Then, he went back to his father, and after 
many, many years of a happy life on earth, he went to the kingdom of Brahman forever!

\section{Lesson Learnt from The Story of Nachiketa.}

1) Nachiketa's deep respect and love for his father, and his selfsacrifice to protect his father's ceremony.

2) Keeping one's word Nachiketa's father kept his word even at the cost of intense grief upon sending his son to the Lord of Death!

3) Nachiketa's steadfastness Even the Lord of Death couldn't sway him from his goal!

4) Shreyas and Preyas - The 'Good' and the 'Pleasant'. The Pleasant is easy but does not make you better or stronger. The Good is difficult, but right in the end.

\section{Conclusion}

Storytelling is the original form of teaching and has the potential of fostering emotional intelligence and help the child gain insight into human behavior. Storytelling also promotes language learning by enriching learners' vocabulary and acquiring new language structures. Moreover, storytelling can provide a motivating and low anxiety context for language learning. Therefore, many EFL (English as a Foreign Language) are interested in storytelling as a resource in teaching. Teacher should choose an appropriate story. A good story to build children's character must have positive moral value. Those kinds of story can be derived from Purana or Upanishad. One of those story from Upanishad that can be used to build a strong and good character as well as training them to learn English for kids in elementary school is the story of Nachiketa. The Storu of Nachiketa derived in English can also be a tool for character building. Several values that can be learnt through Nachiketa story are love and respect towards parent, keeping one's word, steadfastness, shreyas and preyas. 


\section{REFERENCES}

Chaudron, C. (1988). Second Language Classrooms [Elektronisk resurs] : Research on Teaching and Learning. Cambridge: Cambridge University Press

Court, D., \& Rosental, E. (2007). Values embodied in children's literature used in early childhood education in Israeli State schools. Early Childhood Education Journal, 34(6), 407-414

Demirel, M. (2009). Self-efficacy beliefs of elementary teachers and school principals for character education. $H . \quad U$. Journal of Education, 37, 36-49.

Dilidüzgün, S. (1996). Contemporary children literature. Istanbul: Yapi Kredi.

Edgington, D. W. (2002). To Promote character education, use literature for children andadolescents. The Social Studies, 93(3), 113-116

Ghosn, I.K (2002). Four good reasons to use literature in primary school ELT. Oxford: Oxford university press.

Isbell, R, Sobol, J, Lindauer, L, Lowrance A. (2004). The Effects of Storytelling and Story Reading on the Oral Language Complexity and Story Comprehension of Young Children. Early
Childhood Education Journal. December, Volume 32, Issue 3,pp 157-163. Available: http://link.springer.com/article /10.1023/B:ECEJ.0000048967.94 189.a3

Karniol, R. (2012). Storybook-Induced Arousal and Preschoolers' Empathic Understanding of Negative Affect in Self, Others, and Animals in Stories. Journal of Research in Childhood Education, 26: 346-358.

Lake, K. (2011). Character education from a children's rights perspective: An Examination of Elementary Students' Perspectives and Experiences. International Journal of Children's Rights. 19 (4), 679690.

Parikh, Janki. 2016. Upanishad Stories for Children: Story of Nachiketa. Retrived from: https://www.speakingtree.in/b log/upanishad-stories-forchildren

Singaporesoleparent.com 2016. Building Childrens character through story telling. Retrived from:

https://www.singaporesolepar ent.com.sg/building-childrenscharacter-storytelling/

Skolverket (2011). Curriculum for the compulsory school, preschool class and the recreation centre 
2011.Stockholm: Skolverket

Available:

www.skolverket.se/publikatio

ner.

Speaker, K. M. (2000). The art of Storytelling: A collegiate connection to professional development schools. Academic journal article. Fall, Vol. 121, No. 1.

Ulusoy, K. \& Dilmaç, B. (2012). Values Education. Ankara: Pegem.

Uzmen, F. S. (2001). Enhancing six year old preschool children's prosocial behaviors by using picture boks Retrieved from, https://tez.yok.gov.tr/UlusalTez Merkezi/tezSorguSonucYeni.jsp

Zeigler, G. R.( 1992). Hommade books to help kids cope. New York: Magination Press 